recorded with very great ground amplitudes at observatories throughout the world (NATURE, December 6,1941, p. 690). To obtain the epicentre of this earthquake, Edward $J$. Walter used the readings of seismograms from twenty-six observatories, mostly in North America and the Pacific Islands, and obtained a tentative epicentre at lat. $37 \cdot 3^{\circ} \mathrm{N}$., long. $19 \cdot 1^{\circ} \mathrm{W}$. This is in the north Atlantic Ocean, between the Azores and Portugal. Undoubtedly, if this earthquake had had an epicentre near any populated area, it would have caused widespread destruction.

\section{Bibliography of Pharmacology and Chemotherapy}

Beginning with Vol. 3 (1942) the name of the "Bibliography of Pharmacology" is changed to "Bibliography of Pharmacology and Chemotherapy". No change in scope is contemplated: "Chemotherapy" is added only to make the title more accurately descriptive. The publication is a reference list of current American and foreign literature relating to the action of known chemical compounds (natural or synthetic) on animal organisms and to therapeutic use of such compounds, including clinical investigations but not including routine clinical and case reports. The annual subseription rate is 3.50 dollars, or 2.50 dollars to members of the Friends of the Hooker Scientific Library. Further information can be obtained from the Hooker Scientific Library, Central College, Fayette, Missouri.

\section{Regnier de Graaf, 1641-73}

Dr. H. R. Catchpole, of the Yale University School of Medicine, has directed attention to the occurrence last year of the tercentenary of the birth of the Dutch physician and anatomist, Regnier de Graaf, who at the age of twenty-two wrote a treatise on the pancreatic juice and when thirty-one discovered the Graafian follicles of the ovary. De Graaf was born at Schoonhove on July 30, 1641, and died at Delft on August 17, 1673, at the early age of thirty-two. He was the son of an architect, and he studied medicine at the University of Leyden. Then he travelled into France, receiving a doctor's degree at Angers and at Paris, making the acquaintance of the savants of the time. Returning to Holland, he settled at Delft, married, and continued the researches for which he is remembered. Haller says his death was occasioned by a very heated dispute he had with Swammerdam.

\section{George Martine}

SIR D'ARCy Thompson has recalled in a recent article (Scotsman, Dec. 27) the work of the eighteenthcentury Scottish physician, George Martine, who died in 1741. Martine went to the University of St. Andrews at the age of thirteen, and later proceeded to Leyden to study under Boerhaave; there he took his M.D. in 1725. He returned to practice in St. Andrews, and at the age of about forty was made fleet surgeon to Admiral Vernon for the Cartagena expedition. Smollett was a surgeon's mate in the same expedition, and Sir D'Arcy believes that his surgeon Macshane in "Roderick Random" was really Martine. Martine died of malarial fever when the expedition was in the Caribbean Sea.

Martine was a good mathematician and natural philosopher as well as a physician, and in Sir D'Arcy's opinion narrowly missed making some of Black's cardinal discoveries. In "De Similibus Animalibus"
(1740) he discussed the effects on the circulation of change of magnitude in an animal, now known as the principle of similitude ; in "De Calore Animalium" (also published in 1740) he dealt with the heat of warm-blooded animals, which he believed was due to friction of the blood on the walls of the blood vessels. He knew that the temperature of the skin of a man is about $97^{\circ}$, while that of dogs, eats, oxen and swine is higher and of birds highest of all. $\mathrm{He}$ wrote several papers on heat and the early history of the thermometers, and had a good notion of an absolute zero. His papers on medical topics included one "On Periods and Crises of Disease", while a paper on a tracheotomy performed in St. Andrews, including a description of a double cannula suggested by "one of our Ministers here" is printed in the Philosophical Transactions of 1730.

\section{Cecil Peace Prize}

A Cecrx Peace Prize of $£ 100$, open to all undergraduates, without distinction of sex or nationality of any university or university college in Great Britain or Northern Ireland, who have attained the age of twenty-five on the last day of submitting essays, is offered for 1942. The subject is: "In what sense did the League of Nations succeed or fail ?" The Prize for the 1941 essay has been awarded to The Hon. N. H. C. Bruce, Oriel College, Oxford; Proxime accesserunt, L./Cpl. R. James, University of Liverpool, and Miss Eileen Taylor, St. Hugh's College, Oxford. Further information can be obtained from the Secretary, University Bureau of the British Empire, c/o University College, Gower Street, London, W.C.1.

\section{X-Ray Analysis in Industry}

The Institute of Physice is arranging a conference on "X-Ray Analysis in Industry" to be held in Cambridge during April 10-11. The purpose of the conference is to promote the interchange of knowledge and experience between those employing $\mathrm{X}$-ray analysis (diffraction methods) in their work in different fields, and to arrange for further collaboration between physicists, engineers, chemists and others towards the solution of problems by its methods. The discussions, which will be based on papers included in the symposium already published by the Institute (J. Sci. Inst., May and July, 1941), will be informal. During the conference, Sir Lawrence Bragg will deliver a lecture on "The History and Development of X-Ray Analysis". Further particulars can be obtained from the Secretary of the Institute of Physics, temporary address, University, Reading, Berks, to whom application for accommodation in Cambridge should be made before February 14 next.

\section{Announcements}

Prof. C. Lovati Evans, Jodrell professor of physiology in University College, London, has been elected an honorary member of the Sociedad Argentina de Biologia.

Captann N. H. Heck, chief of the Division of Terrestrial Magnetism and Seismology of the U.S. Coast and Geodetic Survey, has been awarded the degree of doctor of science by Fordham University, for his distinguished work in connexion with seis. mology. 